\title{
Voluntary Intake, Chemical Composition, and Nutrient Digestibility of Pangolagrass and Stargrass Hays $^{1}$
}

\author{
R. Gutiérrez-Vargas, J. A. Arroyo-Aguilú, and A. Ramírez-Ortizz',
}

\section{ABSTRACT}

Pangolagrass (Digitaria decumbens) and stargrass (Cynodon nlemfuensis) harvested at 30,45 , and 60 days and made into hay, were fed to four castrated male ruminants (goats and steers) in individual digestion stalls. The grasses were fertilized at the rate of $4,480 \mathrm{~kg} / \mathrm{ha} / \mathrm{yr}$ with $15-5-10$, harvested, sun-dried for 2 days and cut in $3-$ to $6-\mathrm{cm}$ pieces. Each experimental period lasted 21 days, divided into a 14-day preliminary feeding period and a 7 -day collection period. Each hay was offered at a level of $90 \%$ intake, as determined in the preliminary period. Hays, offered and refused, and feces were weighed and sampled daily. Representative samples were analyzed for dry matter, crude protein, neutraldetergent fiber, acid-detergent fiber, cellulose, lignin, and silica. Hemicellulose was determined as the difference between neutral-detergent fiber and aciddetergent fiber. Apparent digestion coefficients for each fraction were calculated on all hays and all ruminants.

Pangolagrass dry-matter intake was significantly $(P<.01)$ greater than that of stargrass hay by both goats and steers. No significant differences in dry-matter intake were obtained between hay ages of 30,45 , and 60 days. Goats had a higher dry-matter intake $(P<.01)$ than steers.

Significant differences were obtained between hays in neutral-detergent fiber $(P<.01)$, hemicellulose $(P<.01)$, and cellulose $(P<.05)$ contents and between hay ages in crude protein $(P<.05)$, cellulose $(P<.01)$, lignin $(P<.05)$, and silica $(P<.01)$ contents. For digestibilities, significant differences were obtained between hays in dry matter $(P<.05)$, neutral-detergent fiber $(P<.05)$, and cellulose $(P<.01)$; between hay ages in lignin $(P<.01)$ and silica $(P<.01)$; and between ruminants in dry matter $(P<.01)$, neutral-detergent fiber $(P<.01)$, acid-detergent fiber $(P<.01)$, hemicellulose $(P<.01)$, and cellulose $(P<.01)$. Goats may not necessarily substitute for steers in digestion trials; and lignin, but not silica, tends to be a valid marker for determining digestibility.

\section{INTRODUCTION}

In vivo digestion trials are very important for the determination of nutrient availability and digestibility of forage grasses. Not much information is available on utilization of the fiber fractions, as proposed by Goering and Van Soest (15), for determining nutrient digestibility in vivo. The more recent methodology of analyses, as determined by Van Soest (31), is based on the use of detergents for separating forage constituents into available and unavailable fractions, yielding more precise results.

${ }^{1}$ Manuscript submitted to Editorial Board January 31, 1978.

${ }^{2}$ Data are taken in part from a thesis submitted by the senior author to the Graduate Faculty, College of Agricultural Sciences, University of Puerto Rico, Mayagüez, P.R., in partial fulfillment of the requirements for the degree of Master of Science.

${ }^{3}$ Former graduate student, Animal Industry Department, Faculty of Agriculture, University of Puerto Rico, Mayaguez, P.R.; Nutritionist; and Assistant Animal Husbandman, Agricultural Experiment Station, University of Puerto Rico, Rio Piedras and Lajas, P.R. respectively. 
Dry matter intake (DMI) is just as important as digestibility for the nutritional evaluation of forages $(16,22)$. As a result, it is most important and necessary to study the relationship of DMI to chemical composition and digestibility.

Goats could be very useful as test animals for evaluating forages. Being smaller than steers, goats require less space, consume less feed, and would make in vivo trials easier and less expensive. However, little is known about the comparative nutrient digestibility in these ruminants, especially in the Humid Tropics.

This study comprises the determination of voluntary DMI, chemical composition, and apparent nutrient digestibility of pangolagrass ( $D i g i$ taria decumbens) and stargrass (Cynodon nlemfuensis) and their evaluation using feeding trials with goats and steers.

\section{PROCEDURE}

This study was conducted in 1972 at the University of Puerto Rico Agricultural Experiment Substation at Lajas, located on the southwestern coast at lat. $18^{\circ} \mathrm{N}$. and long. $67^{\circ} \mathrm{W}$. The area, characterized as semiarid, has an average rainfall of $112 \mathrm{~cm}$. The maximum temperature is about $31.1^{\circ} \mathrm{C}$ and the minimum is about $18.3^{\circ} \mathrm{C}$. The soil is classified as Fraternidad clay.

Pangola- and stargrass were grown in pure stands of nonreplicated 0.4ha plots. They were fertilized at the rate of $4,480 \mathrm{~kg} / \mathrm{ha} /$ year with $15-5$ 10. Irrigation was applied at approximately 2 -week intervals during the dry season. Prior to the start of the experiment the plots were cut to a height of $5 \mathrm{~cm}$. The plots were harvested by hand at 30, 45, and 60 days of growth. The grasses were sun-dried for approximately 2 days, providing hays with a DM content of $90 \%$.

The grass hays, cut into 3- to 6-cm pieces, were offered twice a day (7 a.m. and 3 p.m.) to four castrated male ruminants of each species: $1 \frac{1 / 2-}{1}$ year-old native goats and 1-year-old Holstein steers in individual digestion stalls. Animals had free access to water. They were weighed at the beginning and at the end of each collection period. Each experimental period lasted 21 days, divided into a 14-day preliminary feeding period and a 7 -day collection period. During the preliminary feeding period, the hays were offered ad libitum. Voluntary DMI was calculated by substracting DM refused from DM offered. During the collection period, each hay was offered at a level of $90 \%$ intake, as determined in the preliminary period.

Both hays, offered but refused (orts), were weighed daily. Feces were weighed two times a day, at $7 \mathrm{a} . \mathrm{m}$. and at 3 p.m., during the collection period. Hay, orts and fecal samples were collected daily. All samples were oven-dried at $60^{\circ} \mathrm{C}$ for 2 or 3 days to determine field DM. Samples were 
ground in a Wiley mill and passed through a 1-mm screen. Representative samples of hays, orts, and feces were prepared for each ruminant.

$\mathrm{DM}$ and crude protein (CP) contents were determined according to the AOAC methods (4). Goering and Van Soest techniques (15) for cell-wall constituents or neutral-detergent fiber (NDF), acid-detergent fiber $(\mathrm{ADF})$, lignin $(\mathrm{L})$, cellulose $(\mathrm{C})$, and silica (Si) contents were employed. Hemicellulose $(\mathrm{H})$ was determined as the difference between NDF and ADF contents. Apparent digestion coefficients for DM, CP, NDF, ADF, C, H, L, and Si were calculated for all hays.

Data were analyzed according to a $2 \times 3 \times 2$ factorial design of Snedecor and Cochran (27) and the treatment means tested with Duncan's (11) multiple $t$ test.

\section{RESULTS AND DISCUSSION}

VOLUNTARY INTAKE

Mean DMI by goats and steers of pangola- and stargrass hays at 30 , 45, and 60 days of growth is presented in tables 1 and 2. Pangolagrass DMI was significantly $(\mathrm{P}<.01)$ greater than that of stargrass hay by both goats and steers. Similar values were obtained by Arroyo-Aguilú ét al. (2) in bovines consuming pangola-, congo- (Brachiaria ruziziensis), and stargrasses. However, there were no significant differences in DMI of these grasses.

No significant differences in DMI were obtained between $30-, 45-$, and 60 -day hays. Weston (32) indicated that forage fiber exerts a greater influence on DMI than on DM digestibility. Van Soest (30) concluded that fiber mass inhibits intake in forages with a high NDF content and appears to become limiting when NDF content lies between 50 and $60 \%$ of the forage DM. Karue and Evans (19) related voluntary DMI inversely to omasum and intestinal contents of steers and suggested that fiber intake may be limited by the capacities of the omasum and the intestines, probably via the central nervous system.

Goats had a higher DMI $(\mathrm{P}<.01)$ than steers (table 2). In Zambia, Gihad (13) concluded that the advantages of higher DMI (lower water consumption and higher digestive ability of crude fiber) give goats a special ecological niche in the tropics. Mackenzie (20) indicated that the capacity of the digestive system of goats is proportionately larger than that of steers. The higher DMI observed in goats is probably responsible for the larger relative capacity of the digestive system of this ruminant. It has been demonstrated that goats distinguish the four basic tastes: sweet, sour, salty, and bitter, and tolerate better the bitter tastes than do steers $(6,14)$. Malechek and Leinweber (21) reported that goats can subsist on nutrition levels considered substandard for other ruminants. 
TABLE 1.-Mean daily dry matter intake and chemical composition of pangolagrass and stargrass hays at 30,45, and 60 days of age consumed by goats and steers

\begin{tabular}{|c|c|c|c|c|c|c|c|c|}
\hline Grass age & $\mathrm{DMI}^{1}$ & $\mathrm{CP}$ & NDF & $\mathrm{ADF}$ & $\mathrm{H}$ & $\mathrm{C}$ & L & $\mathrm{Si}$ \\
\hline Days & $\mathrm{Kg} / 100 \mathrm{~kg} \mathrm{~W}$ & & & & $\%$ & & & \\
\hline \multicolumn{9}{|c|}{ Pangola-Goats } \\
\hline 30 & 2.0 & 5.8 & 72.7 & 43.8 & 28.9 & 31.9 & 6.7 & 4.8 \\
\hline 45 & 2.2 & 7.5 & 72.3 & 45.7 & 26.6 & 35.9 & 6.4 & 3.2 \\
\hline 60 & 1.9 & 7.3 & 73.8 & 45.1 & 28.7 & 35.8 & 6.2 & 2.7 \\
\hline Mean & 2.0 & 6.9 & 72.9 & 44.9 & 28.0 & 34.5 & 6.4 & 3.6 \\
\hline \multicolumn{9}{|c|}{ Pangola-Steers } \\
\hline 30 & 1.7 & 5.7 & 72.8 & 44.3 & 28.5 & 32.0 & 7.0 & 5.0 \\
\hline 45 & 1.8 & 7.5 & 72.4 & 44.7 & 27.7 & 35.9 & 6.5 & 3.0 \\
\hline 60 & 1.5 & 7.3 & 74.2 & 46.9 & 27.3 & 36.0 & 6.2 & 2.5 \\
\hline Mean & 1.7 & 6.8 & 73.1 & 45.3 & 27.8 & 34.6 & 6.6 & 3.5 \\
\hline \multicolumn{9}{|c|}{ Star-Goats } \\
\hline 30 & 1.7 & 7.8 & 77.0 & 43.3 & 33.7 & 32.8 & 6.4 & 3.6 \\
\hline 45 & 1.9 & 7.2 & 77.7 & 44.6 & 33.1 & 34.4 & 6.9 & 2.7 \\
\hline 60 & 1.7 & 6.6 & 76.9 & 44.7 & 32.2 & 34.5 & 6.2 & 3.5 \\
\hline Mean & 1.8 & 7.2 & 77.2 & 44.2 & 33.0 & 33.9 & 6.5 & 3.3 \\
\hline \multicolumn{9}{|c|}{ Star-Steers } \\
\hline 30 & 1.6 & 7.7 & 77. I & 44.1 & 33.0 & 33.0 & 6.7 & 3.7 \\
\hline 45 & 1.4 & 7.1 & 77.5 & 48.6 & 28.9 & 34.2 & 7.1 & 3.0 \\
\hline 60 & 1.5 & 6.6 & 76.9 & 43.5 & 33.4 & 34.5 & 6.3 & 3.5 \\
\hline Mean & 1.5 & 7.1 & 77.2 & 45.4 & 31.8 & 33.9 & 6.7 & 3.4 \\
\hline
\end{tabular}

${ }^{1} \mathrm{DMI}$, dry matter intake; $\mathrm{CP}$, crude protein; NDF, neutral-detergent fiber; ADF, aciddetergent fiber; $\mathrm{H}$, hemicellulose; $\mathrm{C}$, cellulose; L, lignin; $\mathrm{Si}$, silica; $\mathrm{W}$, body weight.

TABLE 2.-Chemical composition of pangola-and stargrass hays of 30, 45, and 60 days of age and mean daily dry matter intake as consumed by goats and steers

\begin{tabular}{|c|c|c|c|c|c|c|c|c|}
\hline Variable & $\mathrm{DMI}^{1}$ & $\mathrm{CP}$ & NDF & $\mathrm{ADF}$ & $\mathrm{H}$ & $\mathrm{C}$ & $\mathrm{L}$ & $\mathrm{Si}$ \\
\hline & $\begin{array}{r}\mathrm{Kg} / 100 \quad \mathrm{~kg} \\
W\end{array}$ & & & & 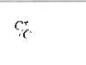 & & & \\
\hline \multicolumn{9}{|l|}{ Hay } \\
\hline Pangola & $1.9 \mathrm{a}^{2}$ & $6.8 \mathrm{a}$ & $73.0 \mathrm{a}$ & $45.1 \mathrm{a}$ & $27.9 \mathrm{a}$ & $34.6 \mathrm{a}$ & $6.5 \mathrm{a}$ & $3.5 \mathrm{a}$ \\
\hline Star & $1.6 \mathrm{~b}$ & $7.2 \mathrm{a}$ & $77.2 \mathrm{~b}$ & $44.8 \mathrm{a}$ & $32.4 \mathrm{~b}$ & $33.9 \mathrm{~b}$ & $6.6 \mathrm{a}$ & $3.3 \mathrm{a}$ \\
\hline \multicolumn{9}{|c|}{ Grass age-days } \\
\hline 30 & $1.8 \mathrm{a}$ & $6.8 \mathrm{a}$ & $74.9 \mathrm{a}$ & $43.9 \mathrm{a}$ & $31.0 \mathrm{a}$ & $32.4 \mathrm{a}$ & $6.7 \mathrm{a}$ & $4.3 \mathrm{a}$ \\
\hline 45 & $1.8 \mathrm{a}$ & $7.3 \mathrm{~b}$ & $75.0 \mathrm{a}$ & $45.9 \mathrm{a}$ & $29.1 \mathrm{a}$ & $35.1 \mathrm{~b}$ & $6.7 \mathrm{a}$ & $3.0 \mathrm{~b}$ \\
\hline 60 & $1.6 \mathrm{a}$ & $6.9 \mathrm{a}$ & $75.5 \mathrm{a}$ & $45.1 \mathrm{a}$ & $30.4 \mathrm{a}$ & $35.2 \mathrm{a}$ & $6.2 \mathrm{~b}$ & $3.1 \mathrm{~b}$ \\
\hline \multicolumn{9}{|l|}{ Ruminant } \\
\hline Goats & $1.9 \mathrm{a}$ & $7.0 \mathrm{a}$ & $75.1 \mathrm{a}$ & $44.5 \mathrm{a}$ & $30.6 a$ & $34.2 \mathrm{a}$ & $6.5 a$ & $3.4 \mathrm{a}$ \\
\hline Steers & $1.6 \mathrm{~b}$ & $7.0 \mathrm{a}$ & $75.1 \mathrm{a}$ & $45.4 \mathrm{a}$ & $29.7 \mathrm{a}$ & $34.3 \mathrm{a}$ & $6.6 \mathrm{a}$ & $3.4 \mathrm{a}$ \\
\hline
\end{tabular}

${ }^{1}$ DMI, dry matter intake; CP, crude protein; NDF, neutral-detergent fiber; ADF, aciddetergent fiber; $\mathrm{H}$, hemicellulose; $\mathrm{C}$, cellulose; $\mathrm{L}$, lignin; $\mathrm{Si}$, silica; $\mathrm{W}$, body weight.

${ }^{2}$ Mean values followed by one letter in common do not differ significantly at the $5 \%$ level. 
Due to this greater tolerance, goats probably consume a larger variety of plant species of lower feeding value than do sheep or steers.

\section{CHEMICAL COMPOSITION}

Chemical components of hay species, hay ages, and ruminant species are presented in tables 1 and 2. Significant differences in NDF and H (P $<.01)$, and in $\mathrm{C}(\mathrm{P}<.05)$ contents were obtained between hays, stargrass being superior to pangolagrass hay in NDF and $\mathrm{H}$ but not in $\mathrm{C}$. Hays did not differ significantly in $\mathrm{CP}, \mathrm{ADF}, \mathrm{L}$, and $\mathrm{Si}$.

The largest percentage change between the two hays was 4.5 percentage units, obtained in $\mathrm{H}$ content. The difference in NDF content between hays could be attributed to the $\mathrm{H}$ difference, since ADF, C, L, and $\mathrm{Si}$ contents did not present marked differences. Arroyo-Aguilú et al. (3) obtained similar results in $\mathrm{CP}, \mathrm{ADF}$, and $\mathrm{C}$ contents in pangola- and stargrass hays.

$\mathrm{CP}$ content increased in hays $(\mathrm{P}<.05)$ between 30 and 45 days and decreased between 45 and 60 days of growth. At younger growth stages, $\mathrm{CP}$ tends to be higher than at more mature stages in all grasses (3). In coarser hays, a tendency for NDF and ADF increase was evident. However, no significant differences in NDF and ADF contents were obtained between ages. For $\mathrm{C}$ content, the increase was significant between $30-$ and 45-day hays $(\mathrm{P}<.01)$ and 30 - and 60 -day hays $(\mathrm{P}<.01)$. Similar results were obtained by Arroyo-Aguilú et al. (3), Coward-Lord et al. (19), Oporta-Téllez (24), and Yazman et al. (33) in various tropical forage species.

$\mathrm{H}$ content did not vary significantly between hay ages, being highest at 30 days and lowest at 45 days of growth. This finding agrees with results obtained by Arroyo-Aguilú et al. (3), Minson (23), and Sullivan (28). They indicated that $\mathrm{H}$ content was not significantly correlated with plant age, since an irregular $\mathrm{H}$ variation was observed with advance in maturity.

Si decreased significantly $(\mathrm{P}<.01)$ between 30 - and 45 -day hays and 30 - and 60-day hays. L decreased significantly $(\mathrm{P}<.05)$ between 30 - and 60 -day hays and 45- and 60-day hays. Yazman et al. (33) observed that L increased slightly in stargrass hay from 30 to 45 days of growth but decreased between 45 and 60 days of growth.

No significant differences in chemical components were obtained between ruminents.

\section{DIGESTION COEFFICIENTS}

Digestion coefficients for the two hays at three growth stages in the two ruminant species are presented in tables 3 and 4 . Between hays, there were significant differences in $\mathrm{DM}$ and in NDF $(\mathrm{P}<.05)$ and in $\mathrm{C}(\mathrm{P}<$ .01) digestibilities, these being higher in pangola- than in stargrass hay. 
TABLE 3.-Mean nutrient digestibility of pangola-and stargrass hays of grasses 30, 45, and 60 days of age consumed by goats and steers

\begin{tabular}{|c|c|c|c|c|c|c|c|c|}
\hline Grass age & $\mathrm{DM}^{1}$ & $\mathrm{CP}$ & NDF & ADF & $\mathrm{H}$ & $\mathrm{C}$ & $\mathrm{L}$ & $\mathrm{Si}$ \\
\hline Days & & & & $\%$ & & & & \\
\hline \multicolumn{9}{|c|}{ Pangola-Goats } \\
\hline 30 & 49.0 & 36.9 & 53.3 & 44.8 & 66.3 & 57.4 & 9.9 & 10.4 \\
\hline 45 & 47.6 & 39.4 & 50.2 & 45.3 & 58.0 & 56.8 & 1.9 & 6.7 \\
\hline 60 & 48.5 & 36.6 & 52.7 & 46.7 & 62.1 & 60.4 & -9.7 & -22.6 \\
\hline Mean & 48.4 & 37.6 & 52.1 & 45.6 & 62.1 & 58.2 & .7 & -1.8 \\
\hline \multicolumn{9}{|c|}{ Pangola-Steers } \\
\hline 30 & 48.7 & 37.1 & 54.1 & 46.9 & 65.4 & 62.8 & 5.3 & 2.5 \\
\hline 45 & 54.7 & 46.6 & 58.0 & 52.6 & 65.2 & 66.3 & 5.6 & 5.2 \\
\hline 60 & 52.0 & 38.1 & 58.1 & 54.1 & 65.9 & 68.5 & -6.5 & -39.4 \\
\hline Mean & 51.8 & 40.6 & 56.7 & 51.2 & 65.5 & 65.9 & 1.5 & 10.6 \\
\hline \multicolumn{9}{|c|}{ Star-Goats } \\
\hline 30 & 46.8 & 48.6 & 50.9 & 41.2 & 63.3 & 55.7 & -4.8 & -14.9 \\
\hline 45 & 44.1 & 35.1 & 49.1 & 42.1 & 58.9 & 51.5 & .9 & -19.7 \\
\hline 60 & 42.0 & 30.3 & 44.0 & 36.1 & 54.6 & 49.1 & -13.4 & -10.9 \\
\hline Mean & 44.3 & 38.0 & 48.0 & 39.8 & 58.9 & 52.1 & 5.8 & -15.2 \\
\hline \multicolumn{9}{|c|}{ Star-Steers } \\
\hline 30 & 49.4 & 46.4 & 54.0 & 45.0 & 65.9 & 60.4 & -2.2 & -6.6 \\
\hline 45 & 52.3 & 40.7 & 57.8 & 54.0 & 67.3 & 66.0 & 5.0 & -14.1 \\
\hline 60 & 49.0 & 43.5 & 53.7 & 54.1 & 64.0 & 61.5 & -4.5 & -17.3 \\
\hline Mean & 50.2 & 43.5 & 55.2 & 51.0 & 65.7 & 62.6 & -.6 & -12.7 \\
\hline
\end{tabular}

${ }^{1} \mathrm{DM}$, dry matter; CP, crude protein; NDF, neutral-detergent fiber; ADF; acid-detergent fiber; $\mathrm{H}$, hemicellulose; $\mathrm{C}$, cellulose; L, lignin; $\mathrm{Si}$, silica.

TABLE 4.-Mean nutrient digestibility of pangola-and stargrass hays of grasses 30, 45, and 60 days of age as consumed by goats and steers

\begin{tabular}{|c|c|c|c|c|c|c|c|c|}
\hline Variable & $\mathrm{DM}^{1}$ & $\mathrm{CP}$ & $\mathrm{NDF}$ & $\mathrm{ADF}$ & $\mathrm{H}$ & $\mathrm{C}$ & $\mathrm{L}$ & $\mathrm{Si}$ \\
\hline & \multicolumn{8}{|c|}{$\%$} \\
\hline \multicolumn{9}{|l|}{ Hay } \\
\hline Pangola & $50.1 \mathrm{a}^{2}$ & $39.1 \mathrm{a}$ & $54.4 \mathrm{a}$ & $48.4 \mathrm{a}$ & $63.8 \mathrm{a}$ & $62.0 \mathrm{a}$ & $1 . .1 \mathrm{a}$ & $-6.2 \mathrm{a}$ \\
\hline Star & $47.3 \mathrm{~b}$ & $40.8 \mathrm{a}$ & $51.6 \mathrm{~b}$ & $45.4 \mathrm{a}$ & $62.3 \mathrm{a}$ & $57.4 \mathrm{~b}$ & $-3.2 \mathrm{a}$ & $-13.9 \mathrm{a}$ \\
\hline \multicolumn{9}{|l|}{ Grass age- } \\
\hline $30 \mathrm{~d}$ & $48.5 \mathrm{a}$ & $42.3 \mathrm{a}$ & $53.1 \mathrm{a}$ & $44.5 \mathrm{a}$ & $65.2 \mathrm{a}$ & $59.1 \mathrm{a}$ & $2.1 \mathrm{a}$ & $-2.2 \mathrm{a}$ \\
\hline $45 \mathrm{~d}$ & $49.7 \mathrm{a}$ & $40.5 \mathrm{a}$ & $53.8 \mathrm{a}$ & $48.5 \mathrm{a}$ & $62.4 \mathrm{a}$ & $60.2 \mathrm{a}$ & $3.4 \mathrm{a}$ & $-5.5 \mathrm{a}$ \\
\hline $60 \mathrm{~d}$ & $47.9 \mathrm{a}$ & $37.1 \mathrm{a}$ & $52.1 \mathrm{a}$ & $47.8 \mathrm{a}$ & $61.6 \mathrm{a}$ & $59.9 \mathrm{a}$ & $-8.5 \mathrm{~b}$ & $-22.6 \mathrm{~b}$ \\
\hline \multicolumn{9}{|l|}{ Ruminant } \\
\hline Goats & 46.3 a & $37.8 \mathrm{a}$ & $50.0 \mathrm{a}$ & $42.7 \mathrm{a}$ & $60.6 \mathrm{a}$ & $55.1 \mathrm{a}$ & $-2.5 \mathrm{a}$ & $-8.5 \mathrm{a}$ \\
\hline Steers & $51.0 \mathrm{~b}$ & $42.1 \mathrm{a}$ & $56.0 \mathrm{~b}$ & $51.1 \mathrm{~b}$ & $65.6 \mathrm{~b}$ & $64.3 \mathrm{~b}$ & $.5 \mathrm{a}$ & $-11.6 \mathrm{a}$ \\
\hline
\end{tabular}

'DM, dry matter; $\mathrm{CP}$, crude protein; NDF, neutral-detergent fiber; ADF, acid-detergent fiber; $\mathrm{H}$, hemicellulose; C, cellulose; L, lignin; $\mathrm{Si}$, silica.

${ }^{2}$ Mean values followed by one letter in common do not differ significantly at the $5 \%$ level. 
However, no significant differences were observed in $\mathrm{CP}, \mathrm{ADF}, \mathrm{H}, \mathrm{L}$, and Si digestibilities.

Mean values of 1.1 and $-3.2 \%$ for $\mathrm{L}$ digestibilities were obtained in pangola- and stargrass hays, respectively (table 4). This demonstrated that $\mathrm{L}$ is a rather inert substance in the ruminant digestive process. Various authors $(7,12,18,26)$ considered $\mathrm{L}$ as an internal indicator in ruminant digestion trials. Ramírez-Reyes (26) obtained a satisfactory $\mathrm{L}$ fecal recovery when parágrass (Brachiaria mutica) was consumed by steers. Arroyo-Aguilú and Evans (1) obtained similar results with steers in low-fiber ration trials. They concluded that $\mathrm{L}$ is a valid marker and has the desirable characteristic of being a constituent of ruminant feedstuffs. Porter (25) suggested that L, as measured by the acid-pepsin technique, undergoes more extensive changes than the acid-detergent $\mathrm{L}$, introduced by Van Soest (29). On the contrary, Jones et al. (17) obtained high $\mathrm{L}$ digestion coefficients in goats and sheep consuming alfalfa (Medicago sativa) hay. Oporta-Téllez (24) also obtained similar results with guinea- (Panicum maximum) and merkergrass (Pennisetum purpureum) hays, and concluded that $\mathrm{L}$ is not a valid marker for use in digestibility studies.

Negative Si digestibilities were obtained in pangola- and stargrass hays (tables 3 and 4). Combellas et al. (8) obtained a mean Si digestibility of $-40.2 \%$ in 23 tropical grasses. Similarly, Oporta-Téllez (24) reported Si digestibilities of -13.5 and $-13.8 \%$ in guinea- and merkergrass hays, respectively. They attributed these results to errors in the sampling system, whereby part of the contaminant $\mathrm{Si}$ was lost. However, Si was not lost in the feces, thus resulting in a $\mathrm{Si}$ fraction greater than in the hays.

Significant $(\mathrm{P}<.01)$ differences in $\mathrm{L}$ digestibility were obtained in hays between 30 and 60 days and 45 and 60 days of growth. Si digestibility varied significantly in hays between 30 and 60 days $(P<.01)$ and 45 and $60(\mathrm{P}<.05)$ days of growth. No significant differences between ages in the other components were observed.

Arroyo-Aguilú et al. (3), Coward-Lord et al. (9) and Oporta-Téllez (24) indicated that, as forage grasses matured, CP decreased and NDF increased, with a reduction in the digestibility of both fractions. In this study, nutrient digestion coefficients, except $\mathrm{L}$ and $\mathrm{Si}$, did not vary significantly as hays advanced in age. An irregular variation in nutrient digestibility, with the exception of $\mathrm{CP}$ and $\mathrm{H}$, was observed. Probably this is due to the great variation between animals in the same trial. Furthermore, the use of few animals per trial limited the accuracy of the results.

Steers were significantly $(\mathrm{P}<.01$ ) higher than goats in DM, NDF, $\mathrm{ADF}, \mathrm{H}$, and $\mathrm{C}$ digestibilities. However, no significant differences between 
ruminant species were observed in $\mathrm{CP}, \mathrm{L}$, and Si digestibilities, although values were higher in steers than in goats for $\mathrm{CP}$ and $\mathrm{L}$. There is need for more research comparing these two ruminant species. In guinea- and merkergrass hays, Oporta-Téllez (24) did not find significant differences between goats, sheep, and steers in nutrient digestibility and concluded that goats could substitute for either sheep or steers in digestion trials. Similar conclusions were drawn by Baumgardt et al. (5) with goats and sheep and by Jones et al. (17), with goats and steers. Nevertheless, little is known about the comparative digestibilities of goats and other ruminants $(5,9)$.

It is concluded that pangolagrass DMI was greater than that of stargrass in goats and steers, that there was a tendency for lower nutritive value with advance in hay age, that goats may not necessarily substitute for steers in digestion trials and that $\mathrm{L}$, but not $\mathrm{Si}$, tends to be a valid marker for determining digestibility. More research needs to be conducted using a wider variety of forages at different growth stages with various ruminant species.

\section{RESUMEN}

Las gramineas Pangola (Digitaria decumbens) y Estrella (Cynodon nlemfuensis), coeschadas a 30, 45 y 60 dias de edad y henificadas, fueron evaluadas en pruebas de digestibilidad con cuatro cabros y cuatro novillos castrados. Las gramíneas se abonaron a razón de 4480 $\mathrm{kg} / \mathrm{ha} /$ año con un análisis 15-5-10, se henificaron por 2 días y se cortaron en trozos de 3 a $6 \mathrm{~cm}$. Cada período experimental duró 21 días, de los cuales los primeros 14 días constituyeron un periodo preliminar de alimentación y los restantes 7 días uno de colección total. Cada heno se ofreció a un nivel de consumo de $90 \%$ del determinado en el período preliminar. Los henos, ofrecidos y rechazados, y las heces, se pesaron diariamente. Las muestras representativas tomadas diariamente se analizaron para materia seca, proteina bruta, fibra neutrodetergente, fibra ácidodetergente, celulosa, lignina y sílice. La hemicelulosa se determinó como la diferencia entre la fibra neutrodetergente y la fibra ácidodetergente. Se calcularon los coeficientes de digestibilidad aparente para cada heno en cada rumiante.

El consumo de materia seca del heno de Pangola fue significativamente $(\mathrm{P}<.01)$ mayor que el de Estrella tanto por los cabros como por los novillos. No se obtuvieron diferencias significativas en consumo de materia seca entre henos, de edades de 30, 45 y 60 días. Los cabros consumieron más materia seca $(\mathrm{P}<.01)$ que los novillos.

Se observaron diferencias significativas entre henos en contenidos de fibra neutrodetergente $(\mathrm{P}<.01)$, hemicelulosa $(\mathrm{P}<.01)$ y celulosa $(\mathrm{P}<.05)$ y entre edades de henos en contenidos de proteína bruta $(\mathrm{P}<.05)$, celulosa $(\mathrm{P}<.01)$, lignina $(\mathrm{P}<.05)$ y sílice $(\mathrm{P}<$ $.01)$. Para las digestibilidades, se observaron diferencias significativas entre henos en materia seca $(P<.05)$, fibra neutrodetergente $(P<.05)$ y celulosa $(P<.01)$; entre edades de henos en lignina $(\mathrm{P}<.01)$ y sulice $(\mathrm{P}<.01)$; y entre rumiantes en materia seca $(\mathrm{P}<.01)$, fibra neutrodetergente $(\mathrm{P}<.01)$, fibra ácidodetergente $(\mathrm{P}<.01)$, hemicelulosa $(\mathrm{P}<.01)$ y celulosa $(\mathrm{P}<.01)$. Los cabros no sustituyen necesariamente a los novillos en pruebas de digestibilidad. La lignina, pero no la sílice, tiende a ser un indicador válido para determinarla.

\section{LITERATURE CITED}

1. Arroyo-Aguilú, J. A., and Evans, J. L., 1970. The use of chromium and acid-detergent lignin in complete rations as indicators of the fecal excretion rate in the ruminant animal, J. Agric. Univ. P.R. 54 (4): 660-75.

2. - Rivera-Brenes, L., De Arce, M., and Acosta-Matienzo, A., 1973. Valor nutritivo y consumo voluntario de las gramíneas Pangola (Digitaria decumbens), Congo (Brachiaria ruziziensis) y Estrella (Cynodon nlemfuensis), ALPA Men. 8: 91-106. 
3. - Tessema, S., McDowell, R. E., Van Soest, P. J., Ramírez, A., and Randel, P. F., 1975. Chemical composition and in vitro digestibility of five heavily fertilized tropical grasses in Puerto Rico, J. Agric. Univ. P.R. 59 (3): 186-98.

4. Association of Official Analytical Chemists, 1970. Official Methods of Analysis, 11th ed, Washington, D.C.

5. Baumgardt, B. R., Byer, W. J., Jumah, H. F., and Krueger, C. R., 1964. Digestion in the steer, goat and artificial rumen as measures of forage nutritive value, J. Dairy Sci. 47: $160-4$.

6. Bell, F. R., 1959. Preference thresholds for taste discrimination in goats, J. Agric. Sci. 52: $125-8$.

7. Colburn, M. W., Evans, J. L., and Ramage, C. H., 1968. Apparent and true digestibility of forage nutrients by ruminant animals, J. Dairy Sci. 51: 1450-7.

8. Combellas, J., González, J. E., and Parra, R. R., 1971. Composición y valor nutritivo de forrajes producidos en el trópico. I. Digestibilidad aparente y verdadera de las fracciones químicas, Agron. Trop. 21: 483-94.

9. Coward-Lord, J., Arroyo-Aguilú, J. A., and García-Molinari, O., 1974. Fibrous carbohydrate fractions and in vitro true and apparent digestibility of 10 tropical forage grasses, J. Agric. Univ. P.R. 58 (3): 293-304.

10. Devendra, C., and Burns, M., 1970. Goat Production in the Tropics, Commonwealth Bureau of Breeding and Genetics, Farnham Royal, Engl.

11. Duncan, D. B., 1955. Multiple range and multiple $F$ tests, Biometrics 11: 1-42.

12. Elam, C. J., Reynolds, P. J., Davis, R. E., and Everson, D. O., 1962. Digestibility studies by means of chromic oxide, lignin, and total collection techniques with sheep, J. Anim. Sci. 189-92.

13. Gihad, E. A., 1976. Intake, digestibility and nitrogen utilization of tropical natural grass hay by goats and sheep, J. Anim. Sci. 43: 879-83.

14. Goatcher, W. D., and Church, D. C., 1970. Taste responses in ruminants. IV. Reactions of pygmy goats, normal goats, sheep and cattle to acetic acid and quinine kydrochloride, J. Anim. Sci. 31: 373-82.

15. Goering, H. K., and Van Soest, P. J., 1970. Forage fiber analyses (apparatus, reagents, procedures and some applications), USDA Agric. Handbook 379.

16. Ingalls, J. R., Thomas, J. W., Benne, E. J., and Tesar, M., 1965. Comparative response of wether lambs to several cuttings of alfalfa, birdsfoot trefoil, brome grass and reed canarygrass, J. Anim. Sci. 24: 1159-64.

17. Jones, G. M., Larsen, R. E., Javed, A. H., Donefer, E., and Gaudreau, J. M., 1972. Voluntary intake and nutrient digestibility of forages by goats and sheep, J. Anim. Sci. 34: 830-8.

18. Kane, E. A., Ely, R. E., Jacobson, W. C., and Moore, L. A., 1953. A comparison of various digestion trial techniques with dairy cattle, J. Dairy Sci. 36: 325-33.

19. Karue, C. N., and Evans, J. L., 1973. Voluntary intake of dry matter by African Zebu cattle: Factors influencing dry matter intake, East Afr. Agric. For. J. 34: 352-60.

20. Mackenzie, D., 1967. Goat Husbandry, 2nd ed, Faber and Faber Publ. Co., London, Engl.

21. Malechek, J. C., and Leinweber, C. L., 1972. Chemical composition and in vitro digestibility of forage consumed by goats on lightly and heavily stocked ranges, $J$. Anim. Sci. 35: 1014-19.

22. Milford, R., and Minson, D. J., 1965. Intake of tropical pasture species, Proc. IX Inter. Grassland Cong. 815-22.

23. Minson, D. J., 1971. The digestibility and voluntary intake of six varieties of Panicurn, Aust. J. Exp. Agric. Anim. Husb. 11: 18-25.

24. Oporta-Téllez, J. A., 1973. Composición química y digestibilidad in vivo e in vitro de los henos de Guinea (Panicum maximum Jacq.) y Merker (Pennisetum purpureum. 
Schum.), M. S. Thesis, Univ. P.R.

25. Porter, P., 1965. Lignin as an inert marker in studies of ruminant digestion, Abstr., Proc. Nut. Soc. 24: VI-VII.

26. Ramirez-Reyes, F., 1972. Comparación del método óxido crómico-lignina con el método convencional para estimar digestibilidad y consumo del pasto Pará (Brachiaria mutica) en bovinos, M. S. Thesis, Univ. P.R.

27. Snedecor, G. W., and Cochran, W. G., 1967. Statistical Methods, 6th ed, The Iowa State Univ. Press, Ames, Iowa.

28. Sullivan, J. T., 1969. Chemical composition of forages with reference to the needs of the grazing animal, A review of recent research findings, ARS, USDA, 34-107.

29. Van Soest, P. J., 1963. Use of detergents in the analysis of fibrous feeds. II. A rapid method for determination of fiber and lignin, J. Assoc. Off. Agric. Chem. 46: 829-35.

30. —, 1965. Symposium on factors influencing the voluntary intake of herbage by ruminants: Voluntary intake in relation to chemical composition and digestibility, $\mathrm{J}$. Anim. Sci. 24: 834-43.

31. - 1967. Development of a comprehensive system of feed analyses and its application to forages, J. Anim. Sci. 26: 119-28.

32. Weston, R. H., 1966. Factors limiting the intake of feed by sheep, 1, The significance of palatability, the capacity of the alimentary tract to handle digesta and the supply of gluconeogenic substrate, Aust. J. Agric. Res. 17: 939-54.

33. Yazman, J. A., Arroyo-Aguilú, J. A., McDowell, R. E., Van Soest, P. J., and Cestero, H., 1977 , Voluntary intake and apparent digestibility of artificially dried Stargrass fed to Holstein bull calves, J. Agric. Univ. P.R. 61(4): 429-37. 